\title{
INFLUENCE OF ADDITIVES ON SUSPENSION STRUCTURE
}

Vesna Savić ${ }^{*}$, Milica Martinović ${ }^{1}$, Ivana Nešić ${ }^{1}$, Jelena Živković ${ }^{1}$, Ivana Gajić ${ }^{2}$

${ }_{1}^{1}$ Department of Pharmacy, Faculty of Medicine, University of Niš, 81 Dr Zoran Đinđić Boulevard, 18000 Niš, Republic of Serbia

${ }^{2}$ Faculty of Technology, Bulevar Oslobođenja 124, 16000 Leskovac, Republic of Serbia
(ORIGINAL SCIENTIFIC PAPER)

UDC 615.45.014.2:661.847.2

DOI $10.5937 /$ savteh2101037S
The aim of this study was to compare the stability and texture of three zinc oxide suspensions with different additives. Suspension 1 was made as official magistral formulation Suspensio album 7.5\% from Formulae magistrales 2008. Suspension 2 was prepared when 1\% carbomer gel was added to suspension 1 and suspension 3 was prepared when polysorbate 20 was added to suspension 2 . After stability tests, texture analysis was performed on all suspensions. Following parameters were measured: hardness cycle 1 , hardness cycle 2 , cohesiveness, adhesiveness, resilience and springiness. The study showed that suspension 3 had the lowest value of hardness, and therefore the best spreadability. Also, suspension 3 was the least sticky of all three, since it was characterized with the lowest adhesiveness. Further, suspension 3 was the most cohesive and is predicted to withstand the stress during packing and use longer than others. On the other hand, the highest values of resilience and springiness were detected for suspension 1 , while the lowest was related to suspension 2 . Therefore, the best textural characteristics were assigned to suspension 3 . This result is in accordance with the results of performed stability tests. The results of our study offer insight into potential improvements of the current magistral formulation Suspensio album $7.5 \%$.
Keywords: suspension, zinc-oxide, texture analysis, carbomer, polysorbate 20

\section{Introduction}

The definition of liquid preparations for topical application is given in European Pharmacopoea 10. Topical suspensions are liquid dosage forms, that are composed of solid particles suspended in a liquid (aqueous or alcoholic) phase in a two-phase system for external cutaneous application. Since suspensions are unstable systems, they have to be shaken before use, so that the homogeneous preparation can be delivered [1].

During the preparation of pharmaceutical suspension, numerous components are added to keep suspension stable and redispersable with a minimum effort. Some of them are wetting agents, flocculating agents, and thickeners. Wetting agents lower the interfacial tension and contact angle between solid particles and liquid vehicle. Thickeners that are adsorbed on particles, increase the strength of the hydration layer formed around suspended solid particles through hydrogen bonding and molecular interaction [2]. Flocculating agents reduce the zeta potential of dispersed particles [3].

Topical therapy is the keystone to the treatment of acute or localized pruritus or other dermatoses when systemic therapy isn't the therapy of choice because of contraindications and polypharmacy [4].

One of the most commonly applied topical suspensions is Suspensio album $7.5 \%$ that acts as astringents. During contact with the skin, the water from the suspension evaporates and leaves a cooling feeling [5]. Therefore, this suspension can be used in the treatment of acne vulgaris, insect bites, seborrhea, pruritus, etc [3].

Several characteristics, such as sensory and texture properties of topical preparations, touch sense, and the feeling during application of the product, are of great importance for patients and consumers since in most cases, the choice of preparation and the compliance of patient largely depends on them [6]. Texture analysis represents a valuable weapon for objective and instrumental assessment of products' structure parameters. Firstly, texture profile analysis (TPA) was applied only to food [7]. Nowadays, TPA has its valuable place in the formulation of drugs and personal care cosmetics products as well [8]. The patient's compliance largely depends on the organoleptic and structural properties of the preparation to be applied to the skin, which indicates the application properties of the product [9].

The aim of our study was to examine the texture properties of 3 suspensions, which contain different components (wetting agent, flocculating agent, thickening agent) and to compare them in order to be able to

\footnotetext{
*Author address: Vesna Savić, Department of Pharmacy, Faculty of Medicine, University of Niš E-mail: vesna.savic@medfak.ni.ac.rs

The manuscript received: April, 29, 2021.

Paper accepted: May, 22, 2021.
} 
determine the formulation with the best characteristics. Three tested suspensions were firstly subjected to the stability tests (sedimentation test and centrifuge test), and afterwards, texture analysis of all suspensions was performed. The aim was to test whether the most stable suspension also had better structural characteristics than the others.

\section{Experimental}

\section{Preparation of suspensions}

For the purpose of this study, three suspensions were prepared (Table 1). Suspension 1 is prepared according to the instructions given in Formulae magistrales 2008 (MF 2008) for preparation of Suspensio album 7.5\% [5]. The powdered substances (zinc oxide and talc) were ground to an appropriate size and mixed in a laboratory porcelain mortar into a homogeneous mixture. They were wetted with glycerol and the obtained paste was then diluted with water. For the preparation of suspension 2, $1 \%$ carbomer gel was prepared, and added to suspension 1 , while suspension 3 was prepared by addition of polysorbate 20 to the suspension 2 .

Table 1. Qualitative and quantitative compositions (\%, (w/w)) of samples:

\begin{tabular}{|c|c|c|c|c|}
\hline & $\begin{array}{c}\text { Suspension } \\
1\end{array}$ & $\begin{array}{c}\text { Suspension } \\
2\end{array}$ & $\begin{array}{c}\text { Suspension } \\
3\end{array}$ & $\begin{array}{l}\text { Role in the } \\
\text { formulation }\end{array}$ \\
\hline Zinc oxide & 7.5 & 7.5 & 7.5 & Adsorbent \\
\hline Talc & 7.5 & 7.5 & 7.5 & Adsorbent \\
\hline Glycerol, 85\% & 35.0 & 35.0 & 35.0 & Wetting agent \\
\hline Carbomer, $1 \%$ & - & 1.0 & 1.0 & $\begin{array}{c}\text { Thickener, } \\
\text { rheological modifier }\end{array}$ \\
\hline Polysorbate 20 & - & - & 0.1 & $\begin{array}{c}\text { Flocculating agent, } \\
\text { wetting agent }\end{array}$ \\
\hline Purified water & q.s. ad 100 & q.s. ad 100 & q.s. ad 100 & Solvent \\
\hline
\end{tabular}

\section{Sedimentation test}

Physical stability of suspension can be estimated by sedimentation rate of suspended solid substances determination. This test is done by dividing the value of sediment height $(\mathrm{mm})$ after the following time intervals: 5 minutes, 30 minutes, 60 minutes, 90 minutes, 120 minutes, and 24 hours with a total height of the suspension. Obtained acceptable suspension coefficient should be less than 1.

\section{Assessment of stability by centrifugation}

Centrifugation is a widely used technique based on the application of centrifugal force to precipitate heterogeneous mixtures. The deposition of particles depends on their size and density and can be explained by Stokes' law. After 30 minutes of centrifugation (3000 rpm) suspension coefficient was determined for all suspensions, by calculating the ratio of the height of the precipitate and the total height of the suspension.

Texture analysis

In order to examine texture properties of samples, the texture analysis was performed on CT3 Texture Analyzer (Brookfield, AMETEK Inc., USA). Following parameters were set:

\section{- $\quad$ Load cell: $10 \mathrm{~kg}$ \\ - Test speed: $1.0 \mathrm{~mm} / \mathrm{s}$ \\ - $\quad$ Target value: $2 \mathrm{~mm}$ \\ - $\quad$ Trigger load: $5 \mathrm{~g}$. \\ - Cone probe: TA-STF \\ Test type: TPA}

All samples were placed in the sample cups so that $75 \%$ of each cup was filled, and the introduction of air was avoided. Texture Profile Analysis (TPA) test was performed, during which, the probe immersed into samples two times, and the following parameters were measured: hardness cycle 1 , hardness cycle 2 , cohesiveness, adhesiveness, resilience, and springiness. The test was performed in triplicate and the mean values and standard deviations of parameters were calculated from the retrieved TPA report after the procedure.

\section{Results and discussion}

Topical dosage forms, such as topical suspensions, are widely used among patients [10]. Topical suspensions are used for the treatment of numerous skin conditions [11].

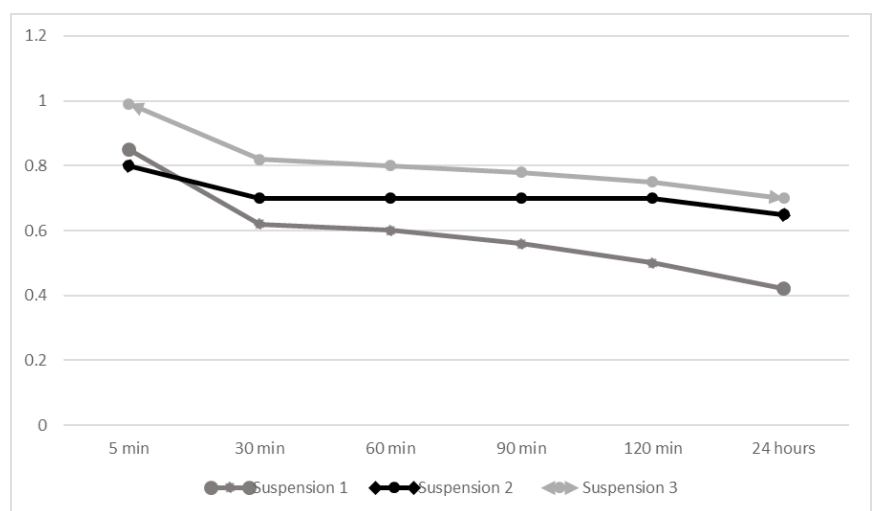

Figure 1. The values of suspension coefficient after following time intervals: 5 minutes, 30 minutes, 60 minutes, 90 minutes, 120 minutes and 24 hours for tested suspensions

The results of stability tests have shown that suspension 1 was the least stable, while suspension 3 was the most stable one, especially after the period of 30 minutes. (Figure 1) The same was observed after the centrifuge test. (Figure 2)

Texture analysis is a mighty tool for the instrumental determination of structural properties of various types of products [9].

During TPA, the texture analyzer is able to measure the following characteristics of tested products: hard- 
ness cycle 1 , hardness cycle 2 , cohesiveness, adhesiveness, resilience, and springiness [12]. The results of the texture analysis are read from the force vs. time curve obtained during two deformation cycles (Figure 3). Hardness cycle 1 and hardness cycle 2 are presented in the graph as maximum forces during both compression cycles. Adhesiveness can be measured from the negative area between the first and second cycle (adhesiveness = area 3 from figure 3 ), while cohesiveness is calculated as the ratio of areas under the curve of the second and first cycle (cohesiveness = area2/area1 from the figure 3). [13]

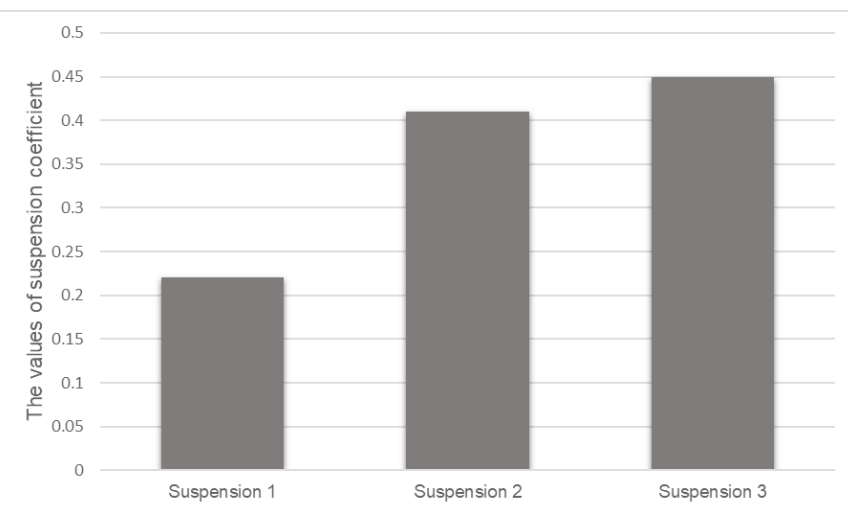

Figure 2. The values of suspension coefficient after $30 \mathrm{~min}-$ utes of centrifugation (3000 rpm) of tested suspensions

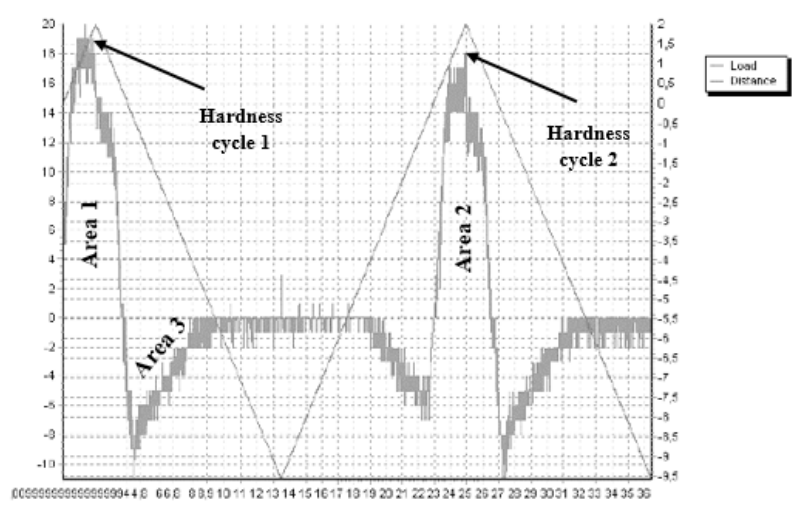

Figure 3. Load (g) vs. time (s) graph obtained during texture analysis of suspension

Table 2. Results of texture analysis of samples

\begin{tabular}{lccc}
\hline & Suspension 1 & Suspension 2 & Suspension 3 \\
\hline Hardness Cycle 1: & $20.00 \pm 1.73$ & $21.00 \pm 0.00$ & $19.67 \pm 1.53$ \\
Hardness Cycle 2: & $17.33 \pm 0.58$ & $19.25 \pm 1.71$ & $17.00 \pm 0.00$ \\
Adhesiveness: & $0.27 \pm 0.06$ & $0.33 \pm 0.13$ & $0.20 \pm 0.00$ \\
Resilience: & $0.63 \pm 0.21$ & $0.53 \pm 0.19$ & $0.60 \pm 0.18$ \\
Cohesiveness: & $0.23 \pm 0.10$ & $0.40 \pm 0.21$ & $0.55 \pm 0.29$ \\
Springiness: & $1.42 \pm 0.46$ & $1.26 \pm 0.42$ & $1.38 \pm 0.38$ \\
\hline
\end{tabular}

Table 2 shows the obtained results of texture analysis of tested suspensions in our study presented as the average value of 3 measures \pm standard deviation.

In TPA, hardness, a force required for obtaining deformation is measured after 2 cycles. Different values of hardness cycle 1 and cycle 2 indicate changes in the structure of suspension after compressions with the probe [13]. Lower values of hardness 2 are probably the result of accelerated sedimentation of suspended solid particles due to compression. From a practical point of view, hardness demonstrates the spreadability of preparation since it shows the force needed to rub the product between the thumb and the forefinger [6]. Therefore, even though all suspensions had close values of hardness, it can be said that suspension 3 has the best "spreadability" profile.

Adhesiveness indicates the stickiness of the product to the skin [6]. The highest adhesiveness was measured for suspension 2, which compared to suspension 1 also contained a thickening agent (carbomer), while the lowest was the adhesiveness of suspension 3 .

Cohesiveness is a parameter that illustrates the strength of internal bonds in the tested sample or "adhesion of the product to itself". A more cohesive product is more able to withstand the stress to which it may be exposed during manufacture, packaging, and use [13]. In our study, it was shown that suspension 3 was the most cohesive, probably because of the added flocculant.

Resilience and springiness are parameters that signal the elasticity of the product. While resilience attributes to the energy necessary for elastic recovery, springiness refers to differences in height of the product before and after the compression [14]. In the case of both parameters, the highest values were measured for suspension 1 while the lowest was measured for suspension 2.

Taken all the parameters into account, it can be said that the best texture properties can be attributed to suspension 3 that contains a thickening agent ( $1 \%$ carbomer gel) and flocculating agent (polysorbate 20). However, further studies should be done, considering various concentrations of more thickening agents, and more different flocculants, since to our knowledge, the textural analyzes of suspensions haven't been performed so far to compare the effects of excipients on the structure of suspensions.

\section{Conclusion}

Topical suspensions are used for the treatment of dermatoses and local skin conditions. Texture analysis offers valuable information for the optimization of topical formulations. The best textural characteristics were observed in a water suspension with zinc oxide that contained a thickening agent (carbomer) and flocculating agent (polysorbate 20). This data can provide insight into potential improvements of current magistral formulation Suspensio album 7.5\% from Formulae Magistrales 2008 that can be more acceptable to patients. 


\section{Acknowledgment}

This research was financially supported by the Ministry of Education, Science and Technological Development of the Republic of Serbia Grant No. TR 31060, and by the Faculty of Medicine, University Niš, Internal Scientific Project No. 67.

\section{References}

[1] The European Pharmacopoeia, $9^{\text {th }}$ ed; Council of Europe: Strasbourg, 2017

[2] Encyclopedia of Pharmaceutical Technology, Second edition, James Swarbrick, James Boylan, 2002, p2663-4

[3] Remington $21^{\text {st }}$ edition The science and practice of pharmacy Lippincott Williams Wilkins p320-323

[4] S. B. Elmariah, E. A. Lerner, in Seminars in cutaneous medicine and surgery, NIH, Public Access 2011, p.118.

[5] G. Vuleta, J. Milić, Magistralne formule: MF 2008. Beograd: Farmaceutsko društvo Srbije, 2008.

[6] G. Savary, L. Gilbert, M. Grisel, C. Picard, Instrumental and sensory methodologies to characterize the residual film of topical products applied to skin, Skin Research and Technology, (2019) 1-9.

[7] W. M. Breene, Application of texture profile analysis to instrumental food texture evaluation, Journal of Texture Studies, 6 (1975) 53-82.
[8] A. Tai, R. Bianchini, J. Jachowicz, Texture analysis of cosmetic/pharmaceutical raw materials and formulations, International Journal of Cosmetic Science, 36(4) (2014) 291-304.

[9] D. S. Jones, A. D. Woolfson, A. F. Brown, Textural, viscoelastic and mucoadhesive properties of pharmaceutical gels composed of cellulose polymers, International Journal of Pharmaceutics, 151 (1997) 223233.

[10] L. Buhse, R. Kolinski, B. Westenberger, A. Wokovich, J. Spencer, C. Chen, S. Turujman, M. Gautam-Basak, G. J. Kang, A. Kibbe, B. Heintzelman, E. Wolfgang, Topical drug classification, International Journal of Pharmaceutics, 295 (2005) 101-112.

[11] A. L. Bunge, Release rates from topical formulations containing drugs in suspension, Journal of Controlled Release, 52 (1998) 141-148.

[12] A. J. Rosenthal, Texture profile analysis-how important are the parameters?, Journal of Texture Studies, 41 (5) (2010) 672-684.

[13] K. T. Trinh, S. Glasgow. On the texture profile analysis test. Institute of Food Nutrition and Human Health, Massey University, New Zealand, 2012.

[14] Texture Technologies, texturetechnologies.com [Date Accessed: 15/03/2021] Avaliable from: https:// texturetechnologies.com/

\section{Izvod \\ UTICAJ POMOĆNIH SUPSTANCI NA STRUKTURU SUSPENZIJA}

Vesna Savić1 ${ }^{1}$ Milica Martinović ${ }^{1}$, Ivana Nešić ${ }^{1}$, Jelena Živković ${ }^{1}$, Ivana Gajić ${ }^{2}$

${ }^{1}$ Katedra za farmaciju, Medicinski fakultet, Univerzitet u Nišu, Bulevar dr Zoran Đinđić 81, 18000 Niš, Republika Srbija

${ }^{2}$ Tehnološki fakultet u Leskovcu, Bulevar oslobođenja 124, 16000 Leskovac, Republika Srbija

Izrađene su tri suspenzije sa cink-oksidom. Suspenzija 1 je napravljena kao zvanična magistralna formulacija Suspensio album 7,5\% iz Magistralnih formula 2008. Suspenzija 2 je pripremljena kada je suspenziji 1 dodat $1 \%$ karbomerni gel, a suspenzija 3 pripremljena kada je suspenziji 2 dodat polisorbat 20. Nakon izvršenih testova stabilnosti, odrađena je teksturna analiza svih suspenzija. Mereni su sledeći parametri: tvrdoća nakon 1. ciklusa, tvrdoća nakon 2. ciklusa, kohezivnost, adhezivnost, rezilijentnost i elastičnost. Rezultati su pokazali da suspenzija 3 ima najmanju vrednost tvrdoće, a samim tim i najbolju razmazivost. Takođe, suspenzija 3 je bila najmanje lepljiva od svih, jer se odlikovala najmanjom adhezivnošću. Pored toga, suspenzija 3 je bila najkohezivnija, što znači da se predviđa da će bolje izdržati stres tokom pakovanja i primene od ostalih. S druge strane, najviše vrednosti rezilijentnosti i elastičnosti izmerene su za suspenziju 1, dok su se najmanje odnosile na suspenziju 2. Stoga se može zaključiti da suspenzija 3 poseduje najbolje teksturne karakteristike. Ovaj rezultat je u skladu sa rezultatima prethodno izvedenih ispitivanja stabilnosti na ovim suspenzijam (test centrifugiranja i određivanje suspenzionog koeficijenta). Rezultati naše studije mogu da služe kao potencijalno poboljšanje trenutne magistralne formulacije Suspensio album 7,5\%.
(ORIGINALNI NAUČNI RAD) UDK 615.45.014.2:661.847.2 DOI 10.5937/savteh2101037S
Ključne reči: suspenzija, cink-oksid, teksturna analiza, karbomer, polisorbat 20 